\title{
Studia
}

SYNCHRONICZNE I DIACHRONICZNE ASPEKTY BADAŃ POLSZCZYZNY

www.wnus.edu.pl/sj | DOI: 10.18276/sj.2019.18-14 | 205-218

\section{Nina PielaCińSKa}

ORCID: 0000-0002-4839-9335

Uniwersytet Szczeciński, Szczecin

nina.pielacinska@usz.edu.pl

\section{Kilka uwag o thumaczeniu portugalskiego fado na przykładzie pieśni Garras dos Sentidos}

\author{
Słowa kluczowe \\ przekład, pieśni portugalskie, poetyka, semantyka \\ Keywords \\ translation, Portuguese songs, poetics, semantics
}

Słowo fado pochodzi od łacińskiego fatum i - jak notuje słownik języka portugalskiego używane jest obecnie w trzech znaczeniach:

1) 'przeznaczenie, szansa, fortuna',

2) 'to, co nieuchronnie się wydarzy, fatum',

3) 'portugalski gatunek muzyczny wykonywany zazwyczaj przy akompaniamencie dwóch gitar: portugalskiej i klasycznej, w tempie wolnym i nostalgicznym, związanym z tematyką miłosną lub saudade ${ }^{1}$, lub też w tempie szybkim i radosnym nastroju, związanym z tematyką krytyki politycznej i społecznej’2.

\footnotetext{
${ }^{1}$ Saudade pochodzi od łacińskiego solitudo (czyli samotność), rozumiane jest jako smutek, nieokreślona tęsknota i nostalgia porównywana do rosyjskiej chandry. Maria Magdalena Starzycka, „Fado”, w: Stownik rodzajów i gatunków literackich, red. Grzegorz Gazda, Słowinia Tynecka-Makowska (Kraków: Universitas, 2006), 244-246.

${ }^{2}$ Dicionário da língua portuguesa: acordo ortográfico (Porto: Porto Editora, 2011) [ttum. N.P].
} 
Przytoczona definicja w odniesieniu do portugalskich pieśni budzi jednak liczne kontrowersje i nie określa w pełni cech konstytutywnych gatunku. Fado, nazywane najczystszym wyrazem portugalskiej duszy, uznawane jest za narodowy symbol kraju i jeden $\mathrm{z}$ bardziej charakterystycznych i złożonych elementów kultury portugalskiej ${ }^{3}$. Istnieje wiele teorii związanych z proweniencją gatunku, większość badaczy jednak uważa, że fado obecne było w Lizbonie od XIX wieku, przechodząc długą drogę z najuboższych warstw społecznych na arystokratyczne salony. Obecnie pieśni te wzbudzają coraz większe zainteresowanie zarówno wśród Portugalczyków, jak i na arenie międzynarodowej. W Portugalii potrzeba retrospektywnej krytyki pojawiła się dopiero na przełomie lat 80. i 90. XX wieku, czyli stosunkowo późno jak na gatunek o ponaddwustuletniej tradycji. Warto także dodać, że wzrost zainteresowania pieśniami fado nastąpił dzięki wpisaniu tego zjawiska kulturowego na listę niematerialnego dziedzictwa UNESCO w 2011 roku, co miało istotny wpływ na promocję i umiędzynarodowienie miejskiego folkloru Lizbony oraz znalazło odzwierciedlenie w publikacjach, których liczba od 2010 roku znacząco wzrosła. Pomimo krytyki purystów gatunku, którzy uważają, że powinno być śpiewane tylko w języku portugalskim i tylko z akcentem lizbońskim, fado zyskuje zwolenników, którzy podejmują się trudnej sztuki przekładu, by dotrzeć do większej liczby odbiorców. Tak arbitralne założenia wykluczyły bowiem z grona fadystów znakomitą większość wykonawców, a nawet królową fado - Amalię Rodrigues, która podczas koncertów śpiewała także w innych językach. Rozwój tego gatunku w Polsce został przeze mnie szerzej opisany w wydanej w 2018 roku monografii pt. Fenomen fado na przykładzie Polski. Poetyka i performance ${ }^{4}$. Warty podkreślenia jest fakt, że wraz z umiędzynarodowieniem fado pojawił się problem z jego definicją i wskazaniem cech określających przynależność gatunkową. W związku z powyższym, na podstawie typologii, proweniencji oraz analiz definicji terminu fado, we wspomnianej monografii sformułowałam oryginalną i kompleksową definicję fado, w której przyjmuję, że jest to:

[...] melodramatyczna pieśń solowa, wpisująca się w nurt folkloru miejskiego. Charakteryzuje się budową stroficzną, śpiewnym tekstem (cantabile), zwykle przedstawia szeroko rozumianą tematykę fatum, jest śpiewana przy akompaniamencie instrumentalnym portamento (z użyciem gitary). Performatywny gatunek powstały w Portugalii w wyniku różnorodnych wpływów kulturowych. Kluczowym elementem fado jest performance - pieśni powinny być wykonywane na żywo i wywoływać głębokie emocje oraz przeżycia u słuchaczy poprzez ekspresyjny przekaz, na który składają się przede wszystkim: sposób śpiewania, mimika i gestyka. Jest to typowy gatunek o fakturze homofonicznej (śpiew monodyczny z akompaniamentem) ${ }^{5}$.

\footnotetext{
3 „Fado, pieśń miejska”, dostęp 21.10.2018, http://www.unesco.pl/kultura/dziedzictwo-kulturowe/dziedzictwo-niematerialne/listy-dziedzictwa-niematerialnego/europa-i-ameryka-polnocna/portugalia.

${ }^{4}$ Nina Pielacińska, Fenomen fado na przyktadzie Polski. Poetyka i performance (Szczecin: Wydawnictwo Naukowe Uniwersytetu Szczecińskiego, 2018).

5 Tamże, 102.
} 
Powyższa definicja zawiera cechy konstytutywne fado do lat 90., ale w opracowaniu przedstawiłam szczegółowo także drugorzędne cechy charakteryzujące gatunek, takie jak struktura tekstu, dominanty tematyczne, akompaniament oraz performance. Stosując przyjęte kryteria i zaproponowaną w pracy definicję, wpisałam twórczość polskich artystów w nurt Novo Fado, będący najnowszym kierunkiem rozwoju badanego gatunku. Szczególnie ważne wydają się być czynniki wpływające obecnie na asymilację tej formy gatunkowej w tak wielu krajach, a tym samym w tak różnorodnych kontekstach kulturowych. W wyniku analiz można jednoznacznie określić związki fenomenu polskiego fado z jego pierwotnym kanonem oraz zauważyć istotne różnice, które powstały w wyniku „przeniesienia” pieśni na potrzeby polskiego odbiorcy.

Niniejszy artykuł stawia sobie za cel przedstawienie kilku uwag związanych z tłumaczeniem tekstów pieśni portugalskich na język polski i stanowi uzupełnienie autorskiej monografii. Przedmiotem analizy jest pierwszy przekład fado na język polski, dla którego reprezentatywna jest pieśń portugalskiej pisarki Agustiny Bessy-Luis ${ }^{6}$ Garras dos Sentidos (,Szpony Zmysłów/Uczuć”), która została przetłumaczona na potrzeby recitalu przygotowanego przez gdański Teatr Wybrzeże. Jest to projekt, który zasłużył na szczególną uwagę, bowiem teksty fado zostały po raz pierwszy zaśpiewane w języku polskim ${ }^{7}$. Celem artykułu nie jest zatem wnikliwa analiza zastosowanych strategii i technik tłumaczeń czy rozstrzygnięcie kwestii związanych z ekwiwalencją ${ }^{8}$, ale przede wszystkim omówienie możliwości przekładu takich elementów struktury dzieła, jak wersyfikacja, układ rymów i semantyka.

Pierwszą fadystką w Polsce jest Marzena Nieczuja Urbańska, śpiewaczka, aktorka gdańskiego Teatru Wybrzeże, która w 2003 roku podjęła się wykonania tych pieśni. Ta gdańszczanka z pochodzenia, absolwentka Studium Aktorskiego przy Teatrze Wybrzeże, rozpoczęła działalność aktorską i reżyserską w Rzeszowie, a od 1987 roku należy już do stałego zespołu gdańskiego teatru. Początkowo pomysł ówczesnego dyrektora Macieja

\footnotetext{
${ }^{6}$ Zdaniem J. Klave, Agustina Bessa-Luis (ur. 1922) uważana jest za najwybitniejszą współczesną portugalską pisarkę. Jest autorką takich dzieł, jak Sibila, Fanny Owen, Vale Abraão, Dominga czy Mosteiro. Napisała biografie wybitnych Portugalczyków: Florbeli Espanki, markiza de Pombala, św. Antoniego Padewskiego oraz Camila Castelo Branco. Jest laureatką nagrody Camõesa i ponad dwudziestu innych wyróżnień literackich. Twórczość autorki charakteryzuje się „zdumiewająco sugestywnym stylem, gdzie układ wyrazów, tonacja, przesunięcie granicy znaczeń podnoszą i rozszerzają wymowę tekstu" - to cechy wyróżniające Bessę-Luis na tle epoki. Janina Klave, Historia literatury portugalskiej - zarys (Wrocław: Zakład Narodowy im. Ossolińskich, 1985), 322.

${ }^{7}$ Wśród polskich artystów, którzy w swojej twórczości zainspirowali się fado, wymienić można Kingę Rataj, Natalię Juśkiewicz, Renatę Przemyk, Annę Marię Jopek, Marka Dyjaka. Innym przykładem „polskiego fado" jest mieszkający i tworzący w Polsce Portugalczyk - João de Sousa, który sam pisze teksty pieśni i który nazwał swój projekt Fado Polaco („Polskie Fado”).

${ }^{8}$ Według E. Balcerzana „tłumaczenie istnieje w serii tłumaczeń. Seria jest podstawowym sposobem istnienia przekładu artystycznego. Na tym polega swoistość jego ontologii. Jeżeli nawet jakiś utwór obcojęzyczny został przetłumaczony na nasz język tylko jeden raz, to przekład ten traktujemy jako początek serii przekładów innych, jakie powstaną lub mogą powstać w przyszłości”. Edward Balcerzan, „Poetyka przekładu artystycznego", w: Literatura z literatury (strategie tlumaczy), red. Piotr Fast (Katowice: Wydawnictwo „Śląsk”, 1998), 18.
} 
Nowaka na zorganizowanie recitalu pieśni fado nie do końca spodobał się aktorce. Należy wspomnieć, że muzyka portugalska nie cieszyła się wtedy popularnością w Polsce, a miejski folklor Lizbony był zjawiskiem nie tylko mało znanym, ale wręcz egzotycznym: ubrany na czarno pieśniarz, stojąc nieruchomo na scenie, śpiewa z zamkniętymi oczami, skupiając na sobie uwagę publiczności. Dość trudny język portugalski dodatkowo ograniczał możliwości odbioru pieśni. Jednak wysoka performatywność fado do tego stopnia zafascynowała aktorkę, że zgodziła się na realizację projektu. Premiera odbyła się 9 października 2003 roku, zaś recital został uznany za największe wydarzenie teatralno-muzyczne i otrzymał Nagrodę Marszałka Województwa Pomorskiego. Ponadto koncerty wzbudzały duże zainteresowanie w wielu miastach w Polsce, a spektakl utrzymywał się w repertuarze teatru przez wiele lat, ciesząc się niesłabnącym uznaniem gdańszczan. Kontynuacją projektu były kolejne recitale Teatru Wybrzeże inspirowane portugalską muzyką: „Fado koncert II” oraz „Fatum”. Można zatem uznać, że Nieczuja Urbańska sprostała zadaniu i polski słuchacz, zupełnie nieznający języka Półwyspu Iberyjskiego, był w stanie poczuć i zrozumieć portugalską mentalność. Co wpłynęło na tak dobry odbiór recitalu? Czy udało się wiernie przekazać treść oryginału polskiemu odbiorcy?

Przekład poezji można uznać za jedno z najtrudniejszych wyzwań, z jakimi musi zmierzyć się tłumacz. Nie sposób podważyć słów Stanisława Barańczaka i jego słynnego dzieła pt. Mały, lecz maksymalistyczny Manifest translatologiczny albo: Ttumaczenie się z tego, że tłumaczy się wiersze również w celu wyttumaczenia innym tłumaczom, iż dla większości ttumaczeń wierszy nie ma wyttumaczenia, w którym poeta wyraźnie zaznaczył, że dokonując przekładu wiersza, podział na „treść” i „formę” nie powinien już istnieć:

Zastąpić go powinno ogólne pojęcie znaczenia rozumianego jako pełnia semantycznego potencjału zawierająca się zarówno w bezpośrednio dostępnych lekturze słowach i zdaniach, jak i w poetyckiej organizacji wypowiedzi. Każdy wybitny utwór poetycki jest miniaturowym modelem świata, i w modelu tym dosłownie każdy element składowy - od sumy wypowiedzianych wprost twierdzeń do najdrobniejszych atomów pozbawionej w zasadzie samodzielnego znaczenia fonetyki, od przynależności gatunkowej czy nawiązań do tradycji aż do wewnątrztekstowych problemów składni czy gramatyki - może dzięki odpowiedniej organizacji tekstu wziąć udział w procesie wytwarzania znaczeń. Wartość estetyczna bierze się w tym procesie stąd, że generowanie znaczeń w danym utworze poddane być może pewnej nadrzędnej zasadzie, która wszystkie znaczeniotwórcze elementy tekstu sprowadza jakby na wspólną płaszczyznę czy nadaje im wspólne ukierunkowanie? .

\footnotetext{
${ }^{9}$ Stanisław Barańczak, „Mały, lecz maksymalistyczny Manifest translatologiczny albo: Tłumaczenie się z tego, że tłumaczy się wiersze również w celu wytłumaczenia innym tłumaczom, iż dla większości tłumaczeń wierszy nie ma wytłumaczenia”, Teksty Drugie. Teoria literatury, krytyka, interpretacja, 3 (1990): 36.
} 
Możemy mówić zatem o prymacie określonego elementu utworu, który nadaje mu sens i stanowi klucz do właściwej interpretacji dzieła. Najważniejszym zadaniem tłumacza jest zatem znalezienie wspomnianego klucza i podporządkowanie mu innych elementów tekstu, które biorą udział w procesie wytwarzania znaczeń. Jest to proces decyzyjny, w którym trzeba rozstrzygnąć, z których elementów można zrezygnować, a które stanowią „nośnik sensu”. Według Barańczaka tłumaczenie jest więc ,interpretacją, która stwarza analogicznie funkcjonujący tekst w języku docelowym. Jeśli dany tekst jest w stanie funkcjonować w języku B i kulturze literackiej B tak samo jak w języku i kulturze A, to mamy wówczas potwierdzenie zrozumienia oryginału i dobrze wykonany przekład"10.

Marzena Nieczuja Urbańska, tworząc repertuar pieśni fado, musiała najpierw dokonać wyboru utworów, które byłyby w stanie dotrzeć do polskiego odbiorcy. Miejski folklor Lizbony często opisuje miasto, jego dzielnice, ulice, kościoły, ważne portugalskie święta, walki byków. Tworzone są portrety codzienności charakterystyczne dla ubogich dzielnic miasta, ale nie są to motywy, z którymi może utożsamić się odbiorca tekstu B, w naszym przypadku Polak. Stąd dominanty tematyczne charakteryzujące wybrane przez Nieczuja Urbańską portugalskie pieśni fado dotyczą głównie uczuć (miłość szczęśliwa, zdrada, niewierność, miłość nieszczęśliwa), przeznaczenia (nieuchronność praw natury, fatalizm) oraz śmierci (żałoba, rozstanie). Na pierwszy recital składają się zatem cztery utwory królowej fado, Amálii Rodrigues (Lágrima, Barco Negro, Fado lisboeta, Estranha forma de vida); sześć pieśni artystki nowego pokolenia fadystów - Mísi (De alguma maneira, Fado do Retorno II, Liberdades poéticas, Garras dos Sentidos, Noite, Não me chamem pelo nome) oraz Canção Do Mar z repertuaru Dulce Pontes. Wybór właśnie takich utworów już na wstępie zwiększył znacząco możliwości odbioru przez polskich słuchaczy.

Tłumaczenie filologiczne poprzedziło ostatni etap pracy, czyli przekład artystyczny, który polega na nadaniu tekstom odpowiedniej formy, by przy akompaniamencie mogły zostać zaśpiewane na scenie w języku polskim ${ }^{11}$. Należy zaznaczyć, że ani Nieczuja Urbańska, ani Tomasz Olszewski (kompozytor, wykonawca i dziennikarz radiowy) nie znali języka portugalskiego, ale na podstawie tłumaczenia heteronomicznego dokonali przekładu artystycznego, starając się uchwycić opisany przez Stanisława Barańczaka „nośnik sensu”. Jak zaznacza aktorka, najistotniejsze z punktu widzenia wykonawcy było estetyczne dopracowanie przekazu fado oraz jego zgodność z frazą muzyczną, natomiast ze względu na oczywiste różnice w obydwu językach nie zawsze było możliwe oddanie rymów lub układu wersów.

\footnotetext{
${ }^{10}$ Barańczak, „Mały, lecz maksymalistyczny”, 11.

${ }^{11}$ Szczegółowo na temat rodzajów przekładów pisze Balcerzan, „Poetyka przekładu”, 17-34; Stanisław Barańczak, „Przekład artystyczny jako «samoistny» i «związany» obiekt interpretacji (na przykładzie niektórych polskich tłumaczeń Gottfrieda Benna", w: Z teorii i historii przektadu artystycznego, red. Jacek Baluch (Kraków: Wydawnictwo Uniwersytetu Jagiellońskiego, 1974), 47-74.
} 
Na szczególną uwagę zasługuje pieśń Garras dos Sentidos ${ }^{12}$, napisana dla fadystki Mísi (właśc. Susana Maria Alfonso de Aguiar) przez Agustinę Bessę-Luis.

Năo quero cantar amores, Amores săo passos perdidos.

Săo frios raios solares, Verdes garras dos sentidos.

Săo cavalos corredores

Com asas de ferro e chumbo, Caídos nas águas fundas.

Năo quero cantar amores.

Paraísos proibidos, contentamentos injustos,

Feliz adversidade,

Amores săo passos perdidos.

Săo demencia dos olhares, Alegre festa de pranto,

Săo furor obediente,

Săo frios raios solares.

Da má sorte defendidos

Os homens de bom juízo

Tem nas măos prodigiosas

Verdes garras dos sentidos.

Năo quero cantar amores

Nem falar dos seus motivos.
Nie chcę śpiewać o mitości

- mitość to stracone chwile

Zimny blask czarnego stońca

Niczym ciernie, uczuć szpony.

Miłość jest jak koń w gonitwie

Co ma ołowiane skrzydta

Zatopiony w morza głębi.

Nie chce śpiewać o mitości.

Miłość to raj zakazany

I niesprawiedliwa radość

Szczęście zawsze zezowate

Mitość to stracone chwile.

Jest jak wzrok opętanego

Festyn, co się w stype zmienit

Szat uniesień udawany

Zimny blask czarnego stońca.

Ci, chronieni wciąż przed pechem

- mężczyźni bardzo ostrożni

$W$ czułych dłoniach swych skrywaja

Niby ciernie uczuć szpony.

Nie chcę śpiewać o mitości

I thumaczyć się, dlaczego.

Pieśń ta stanowi jeden z przykładów zachowania oryginalnej struktury fado, bowiem należy do fado menor, które zaliczane jest do fado castiço. Zarówno według struktury tekstu, jak i struktury muzycznej można wyróżnić dwie główne grupy pieśni - fado castiço i fado-canção. Do pierwszej grupy należą pieśni tradycyjne, charakteryzujące się bardzo dokładną, szablonową wręcz strukturą zarówno w zakresie metryki i wersyfikacji, jak i linii melodycznej. Pieśni z drugiej grupy mają niewiele elementów stałych. Należą do nich m.in. budowa stroficzna (nie zawsze jednak regularna, jak w przypadku fado castiço) oraz powtarzający się refren. Jeśli dana pieśń należy do pierwszej grupy, wówczas powinna mieć

\footnotetext{
12 Zamieszczony w artykule utwór jest własnością Teatru Wybrzeże i pochodzi z prywatnych źródeł. Płyta została wydana w 62 krajach, otrzymała status złotej płyty w Portugalii oraz została włączona na listę stu najlepszych płyt XX w. według Jornal Público; otrzymała także nagrodę Choc de la Musique we Francji.
} 
strofy cztero-, pięcio-, sześcio- lub dziesięciowersowe oraz wersy z określoną liczbą sylab, odpowiednio: cztero-, siedmio-, dziesięcio- lub dwunastozgłoskowe. Jeśli zaś jest to fado-canção, wtedy wersyfikacja może już nie być regularna, obowiązkowo natomiast powinien pojawić się refren przeplatający strofy ${ }^{13}$. Cytowane fado menor charakteryzuje się specyficzną budową związaną z użyciem mote, czyli cztero- bądź sześciowersowej strofy początkowej, po której następuje komentarz ( glosa), każda zaś ze strof glosy zawiera jeden lub dwa wersy z pierwszej strofy (mote). Omawiana pieśń zawiera czterowersową strofę początkową (mote) i glosę - rozwinięcie w postaci czterech czterowersowych strof, z których każda kończy się jednym z wersów strofy początkowej (mote).

W tłumaczeniu na język polski taki układ stroficzny został zachowany, podobnie jak sylabiczna wersyfikacja. Istotna jest jednak liczba sylab, jako że w języku portugalskim wiersz możemy zaklasyfikować jako typowy przykład siedmiozgłoskowca, zaś w języku polskim jest to klasyczny ośmiozgłoskowiec. Zgodnie z polską tradycją wersyfikacyjną „ośmiozgłoskowiec to jeden z trzech, obok jedenastozgłoskowca i trzynastozgłoskowca, najważniejszych wzorów polskiego wiersza sylabicznego. Jest najstarszym z nich i jedynym z całą pewnością rodzimym, ponieważ dwa pozostałe formaty rozwinęły się w polskiej poezji pod wpływem łacińskim, a później włoskim"14. Różnica w tekście oryginalnym i przekładzie wynika ze sposobu liczenia sylab w języku portugalskim, gdzie należy zastosować podział z uwzględnieniem synalef ${ }^{15}$, a także pamiętać o tym, że sylaby liczone są tylko do ostatniej sylaby akcentowanej:

\section{Ver/des $/$ gar $/$ ras $/$ dos $/$ sen $/$ ti $/$ dos $=8-1=7$ \\ $\mathrm{Ni} / \mathrm{czym} / \mathrm{cier} / \mathrm{nie} / \mathrm{u} / \mathrm{czuc} / \mathrm{szpo} / \mathrm{ny}=8$}

W wyniku takiego podziału wszystkie ośmiozgłoskowe wersy portugalskie liczone są jak wersy siedmiozgłoskowe. W przekładach polskich nie uwzględniono zasad portugalskiej fonetyki i tradycji wersyfikacyjnej. Nadrzędną zasadą w odzwierciedleniu formy portugalskiego pierwowzoru było zastosowanie regularnej budowy wersyfikacyjnej, różniącej się jednak od wersji oryginalnej. Pojawiające się różnice gramatyczne, fonetyczne, jak i składniowe między językiem portugalskim a polskim spowodowały, że w większości przekładów wersy tłumaczone są dłuższe od wersów oryginału.

\footnotetext{
${ }^{13}$ Rui Vieira Nery, “A Arte de Dizer”, w: Amália: Coração Independente, red. Clara Távora Vilar, Nuno Ferreira de Carvalho (Lisboa: Fundação Amália Rodrigues / Museu Colecção Berrado / Museu da Electricidade-Fundação EDP, 2009), 105-127.

14 Wiktor Jarosław Darasz, Mały przewodnik po wierszu polskim (Kraków: Towarzystwo Miłośników Języka Polskiego, 2003), 65-66.

${ }^{15}$ Synalefa to zjawisko fonetyczne polegające na ujednoliceniu artykulacji ostatniej sylaby wyrazu zakończonego samogłoską i pierwszej sylaby wyrazu następnego, rozpoczynającego się również samogłoską. W utworach poetyckich wykorzystywana jest jako środek stylistyczny ułatwiający zachowanie odpowiedniego metrum. Szerzej na ten temat: Wiaczesław Nowikow, Fonetyka hiszpańska (Warszawa: Wydawnictwo Naukowe PWN, 1992), 6-63.
} 
Niełatwe dla tłumaczy było również odzwierciedlenie pierwotnego układu rymów. W języku portugalskim rymy możemy podzielić ze względu na miejsce występowania (klauzulowe, wewnętrzne, średniówkowe); sposób powiązania elementów (parzyste, krzyżowe, okalające, mieszane, wolne oraz tzw. encadeadas, w których ostatnia sylaba rymuje się z sylabą występującą w stałym miejscu wewnątrz kolejnego wersu); stosunek do akcentu (męskie, żeńskie i daktyliczne tzw. esdrúxulas, w których akcent pada na trzecią sylabę od końca); dokładność (dokładne, niedokładne); bogactwo (bogate, ubogie, tzw. raras, gdzie rym występuje pomiędzy nietypowymi, rzadko używanymi wyrazami, tzw. preciosas, w których czasownik rymuje się z połączeniem czasownikowo-przyimkowym) ${ }^{16}$.

Zachowanie w przytoczonym utworze regularnych rymów (klauzulowe, krzyżowe, żeńskie) w polskiej wersji językowej okazało się niestety niemożliwe:

Năo quero cantar amores, (A)

Amores săo passos perdidos. (B)

Săo frios raios solares, (A)

Verdes garras dos sentidos. (B)
Nie chcę śpiewać o miłości

- miłość to stracone chwile

Zimny blask czarnego słońca

Niczym ciernie, uczuć szpony.

Podobnie jak w innych przetłumaczonych pieśniach fado jest to element, z którego trzeba było zrezygnować na poczet zgodności z frazą muzyczną lub w celu oddania właściwego znaczenia. Dodatkowym utrudnieniem był zatem fakt, że tekstem śpiewanym na scenie rządzą zasady wymowy scenicznej w śpiewie, które determinują większość zjawisk artykulacyjnych. Użycie niektórych wyrazów powodowałoby niezgodność akcentów muzycznych z językowymi i/lub byłoby przyczyną niezrozumiałości tekstu. Potwierdzają to słowa Jerzego Bartmińskiego, który zaznacza: „w śpiewanym tekście strona dźwiękowa słów ulega rozwinięciu i przystosowaniu do funkcji melicznych, strona semantyczna zaś - przytłumieniu i pewnej degradacji"17. Podobnie rzecz się ma w odniesieniu do tłumaczenia treści utworów. Bartmiński pisze, że niekiedy niemożliwe jest dokładne przetłumaczenie tekstu i następuje tzw. ,przytłumienie” strony semantycznej ${ }^{18}$. W przypadku analiz przekładu pieśni fado wykonywanych w Teatrze Wybrzeże zrezygnowano z przybliżenia polskiemu odbiorcy symboli, kolorów i postaci mających szczególne znaczenie dla kultury portugalskiej. Odległość kulturowa nie pozwoliłaby bowiem polskim odbiorcom na odczytanie sensów naddanych.

\footnotetext{
${ }^{16}$ Evanildo Bechara, Moderna Gramática Portuguesa (Rio de Janeiro: Nova Fronteira Participações S.A., 2009), 278-285.

17 Jerzy Bartmiński, „Wymowa w śpiewie”, w: Opuscula logopaedica: in honorem Leonis Kaczmarek, red. Jerzy Bartmiński (Lublin: Wydawnictwo UMCS, 1993), 226-231.

18 Tamże.
} 
Dobrą egzemplifikacją wspomnianego zjawiska jest analizowany tu wiersz Garras dos Sentidos („Szpony Zmysłów/Uczuć”19), w którym tytułowe szpony w tekście są zielone. Jest to jedna z metafor miłości wyrażona przez podmiot liryczny obarczający za wszelkie cierpienia mężczyzn, którzy sami są chronieni przed nieszczęściem, ale skrywając w dłoniach „szpony uczuć”, obejmują nimi kobiety, doprowadzając je do zguby. Znaczącym elementem jest tu bardzo negatywnie nacechowana w języku portugalskim zieleń, konotująca zgubne, destrukcyjne uczucie, z którego nie możemy się wydostać. W kulturze iberyjskiej zieleń bardzo często symbolizuje śmierć, czego przykładem mogą być poematy i dramaty Federica Garcii Lorki (Romance Sonámbulo ${ }^{20}$ ) czy poezja Fernanda Pessoi (Ó ervas frescas que cobris, O sol queima o que toca ${ }^{21}$ ). W sprzeczności z kulturą tekstu pierwotnego pozostaje opis semantyki barwy zielonej na gruncie współczesnej polszczyzny, gdzie zestawiana ze światem roślin, z odradzającym się życiem i wiosną, symbolizuje miłość nowa oraz oddaje szeroki wachlarz pozytywnych doznań emocjonalnych, 'pełni życia', 'nadziei' i 'radości’22. Ryszard Tokarski zaznacza jednak: „niejako na marginesie zasadniczego nurtu znaczeniowego barwy zielonej notuje się takie jej użycia, które ewokują starość, chorobę, zgniliznę czy rozpad. [...] w takich wypadkach właściwe barwie zielonej konotacje 'radości', 'nadziei' [...] są eliminowane, a najstosowniejszą językową techniką kategoryzującą jest uzupełnienie nazwy barwy epitetem modyfikującym zgniła (zieleń)"23.

W tłumaczeniu analizowanej pieśni wyeliminowano barwę i rozszerzono tekst, dodając negatywnie nacechowany rzeczownik ciernie (niczym ciernie, uczuć szpony), aby wydobyć oryginalne znaczenie. Zielone szpony uczuć byłyby bowiem dla polskiego odbiorcy niezrozumiałe, ciernie zaś stają się ekwiwalentem znaczeń konotowanych przez zieleń w języku portugalskim.

W tej samej strofie dodano jednak inną barwę, która kojarzona jest jednoznacznie ze śmiercią. Miłość w tekście oryginalnym porównana została do zimnych promieni słońca (frios raios solares), zaś w polskim przekładzie pojawia się jako zimny blask czarnego stońca. Zimny blask, podobnie jak zimne promienie, to światło, które nie ogrzewa, stanowi zatem własne zaprzeczenie. Może symbolizować światło księżyca, służąc spotęgowaniu ciemności, podkreśleniu bezkresu nocy. Z kolei oksymoron czarne słońce w polskiej wersji wprowadza dodatkowe możliwości interpretacyjne. Konotuje znaczenie obecne w Apokalipsie św. Jana (6, 12-14), w której czarne słońce pojawia się jako zapowiedź końca świata:

\footnotetext{
${ }^{19}$ Uściślając niejako tłumaczenie, należy dodać, że słowo sentidos oznacza w języku portugalskim zmysły, nie zaś uczucia, jak zostało to przełożone na język polski.

${ }^{20}$ Federico García Lorca, Obras completas I, II, III, red. Arturo del Hoyo (Madrid: Aguilar, 1991).

${ }^{21}$ Fernando Pessoa, Poesias Inéditas (1919-1930) (Lisboa: Ática, 1990).

22 Ryszard Tokarski, Semantyka barw we wspótczesnej polszczyźnie (Lublin: Wydawnictwo UMCS, 2004), 126-134.

${ }^{23}$ Tamże, 134.
} 
Gdy otworzył szósta pieczęć, zobaczyłem, że nastapiło wielkie trzęsienie ziemi. Słońce stało się czarne jak wór pokutny, a cały księżyc stał się jak krew. Gwiazdy nieba spadały na ziemie, jak spadaja niedojrzałe figi z figowca wstrzasanego gwałtownym wichrem. Niebo zostało usunięte, zwinięte jak zwój, a każda góra i wyspa zostały przesunięte ze swego miejsca ${ }^{24}$.

Inną symbolikę możemy odnaleźć w pismach Babilonu, gdzie pojawiają się dwa słońca: białe - dające światło dzienne - i czarne - dające siłę wiedzy, a zatem odnosi się ono do wartości duchowych człowieka. W tekstach alchemicznych natomiast czarne słońce (sol niger) jest symbolem Saturna i reprezentuje ciemny oraz niszczycielski aspekt słońca ${ }^{25}$.

Należy jednak pamiętać, że czarne słońce było także ulubioną metaforą polskich romantyków ${ }^{26}$, kojarzącą się bezpośrednio z melancholią ${ }^{27}$ i smutkiem duszy. Rozszerzenie na poziomie semantycznym, czyli użycie w tłumaczeniach portugalskiego fado, które z definicji jest melancholijną pieśnią, właśnie wyrażenia czarne słońce hiperbolizuje smutek oraz uczucie straty podmiotu lirycznego, a zatem doskonale oddaje emocje towarzyszące wykonywaniu utworu. By uwypuklić dramatyzm słów podczas występu na scenie, Nieczuja Urbańska śpiewa używając ozdobników, dzięki czemu rekompensuje niezgodność akcentów w obu językach, podkreślając znaczenie oksymoronu czarne słońce. W tym miejscu nie sposób nie zgodzić się, że „[1]iteracka koncepcja przekładu, choć wiele korzysta z doświadczeń lingwistyki, nie może przyjąć jej modelu wypowiedzi, usiłuje bowiem rozstrzygnąć kłopoty tłumaczy nie na poziomie tekstu, lecz na poziomie utworu, w którym istnieje więcej «planów»" 28 .

\section{Wnioski}

Jak można zaobserwować na wybranym przykładzie, polskie wersje analizowanej pieśni nie zachowały oryginalnego układu rymów ani liczby sylab. Treść utworów została poszerzona o pewne elementy lub ich pozbawiona, by odbiorca tekstu B mógł zrozumieć istotę

\footnotetext{
${ }^{24}$ Pismo Święte Starego i Nowego Testamentu (Częstochowa: Edycja Świętego Pawła, 2009), 2701.

25 Piotr Śniedziewski, „Obraz czarnego słońca w wybranych utworach francuskich i polskich romantyków (rekonesans)", Prace Polonistyczne, 70 (2015): 199-202.

${ }^{26}$ Więcej na ten temat zob. Piotr Śniedziewski, Czarne stońca romantyków (Warszawa: Wydawnictwo Sic!, 2018).

${ }^{27}$ Szerzej na ten temat zob. Julia Kristeva, Czarne słońce. Depresja i melancholia (Kraków: Universitas, 2007). Czarne słońce to według autorki transcendentny symbol smutku, charakterystyczny dla melancholików, który determinuje wszelkie ich działania. „Skąd pochodzi to czarne słońce? Z jakiej niepokojącej galaktyki biorą się jego niedostrzegalne, a uciążliwe promienie, które przykuwają mnie do ziemi, do łóżka, prowadzą do utraty mowy, do rezygnacji?", tamże, 55.

${ }^{28}$ Balcerzan, „Poetyka przekładu”, 25.
} 
fado. Nasuwa się jednak pytanie: w jaki sposób sprawdzić, czy utwory funkcjonują w obydwu kulturach identycznie? Odpowiedź znajdziemy u Stanisława Barańczaka, który pisze:

Sprawdzian najpewniejszy - tu, niestety, od semiotyki musimy przejść do somatyki, ale nie ma innej rady, fizjologia przynajmniej nie kłamie i nie da się sfałszować - to, w szczególnie udanych wypadkach, dreszcz, który nam przebiega po plecach, łza, która się zakręci w oku, albo nieopanowany wybuch śmiechu. Ostatecznie, po co czytamy wiersz? Po to - że powtórzę za Witkacym, który zresztą akurat poezji tego rodzaju potencjału odmawiał - aby jego jedność w wielości przyprawiała nas o dreszcz. Dreszcz metafizyczny, ale i całkiem dosłownie fizjologiczny. Tłumacz poezji tłumaczy zatem nie tylko po to, aby dorównać i przewyższyć, aby oryginalnemu tekstowi złamać kręgosłup jego językowego i formalnego oporu, lecz również po to, aby poczuć dreszcz ekstazy w kręgosłupie własnym. Mówiąc ściślej: po to, aby się dowiedzieć, dlaczego ciarki przeszły mu po krzyżu, kiedy przeczytał oryginał - a dowiedzieć się tego w sposób absolutnie pewny można tylko w jeden sposób: sprawdzając, czy podobne doznanie stanie się naszym udziałem, kiedy odtworzymy utwór w naszym własnym języku ${ }^{29}$.

Fado, czyli miejski folklor Lizbony, jest specyficznym gatunkiem i trudno uchwycić jego istotę, dlatego starając się sprawdzić autentyczność przekazu na wspomnianym przez Barańczaka „poziomie somatycznym”, musimy pamiętać, że kluczowym elementem fado jest performance - pieśni powinny być wykonywane na żywo i wywoływać głębokie emocje oraz przeżycia u słuchaczy poprzez ekspresyjny przekaz, na który składają się przede wszystkim sposób śpiewania, mimika i gestyka.

W przypadku recitalu w Teatrze Wybrzeże możliwość sprawdzenia oddziaływania tekstu na słuchaczy była weryfikowana wielokrotnie podczas licznych koncertów i występów na terenie Polski. Na podstawie własnych obserwacji oraz opinii uzyskanych podczas rozmów z publicznością, o których pisze Grażyna Antoniewicz, mogę jednoznacznie stwierdzić, że siłą występów fadystki jest właśnie zaangażowanie i głęboki kontakt ze słuchaczami, którzy niejako przeżywają tęsknotę, nieszczęśliwą miłość, śmierć czy żal razem ze śpiewaczką:

Pani Marzena Nieczuja Urbańska jest delikatna jak portugalski zmrok i czuła jak lizboński świt. Między zmrokiem i świtem, między czułością a tęsknotą rozgrywają się miłosne sceny piosenek, które być może przypomną widzom uczucia, bez których życie byłoby pozbawione sensu. [...] [Nieczuja Urbańska] zdaje się wpatrywać gdzieś, w głąb swojej duszy. Jakby cała i bez reszty oddając się temu, co zaraz

\footnotetext{
${ }^{29}$ Barańczak, „Mały, lecz maksymalistyczny”, 11 [podkr. - N.P.].
} 
opowie, wypłacze. Śpiewa o utraconych uczuciach, nadziejach, łzach, pożegnaniach i powrotach ${ }^{30}$.

Polska warstwa tekstualna, odbiegająca niekiedy od oryginału w zakresie leksyki czy wersyfikacji, powoduje, że przekaz pieśni jest spójny, zrozumiały i autentyczny dla naszego odbiorcy, wzbudza bowiem silne emocje, którym nierzadko towarzyszą łzy lub śmiech. A zatem w przekładzie artystycznym, który był przedmiotem analizy w niniejszym artykule, można zauważyć prymat dominanty semantycznej, dzięki czemu wymowa tekstu ocalała w tłumaczeniu.

\section{Bibliografia}

\section{Źródło}

Bessa-Luis, Agustina. Garras dos Sentidos (Mísia, 1998).

Antoniewicz, Grażyna. „Bosa Królowa”. Dziennik Battycki. Kultura, 18.04.2005.

Antoniewicz, Grażyna. „Fatum - piosenki inspirowane portugalskim fado”. Dziennik Bałtycki. Kultura, 7.07.2010.

Balcerzan, Edward. „Poetyka przekładu artystycznego”. W: Literatura z literatury (strategie tlumaczy), red. Piotr Fast. Katowice: Wydawnictwo „Śląsk”, 1998, 17-31.

Barańczak, Stanisław. „Mały, lecz maksymalistyczny Manifest translatologiczny albo: Tłumaczenie się $\mathrm{z}$ tego, że tłumaczy się wiersze również w celu wytłumaczenia innym tłumaczom, iż dla większości tłumaczeń wierszy nie ma wytłumaczenia". Teksty Drugie. Teoria literatury, krytyka, interpretacja, 3 (1990), 7-66.

Barańczak, Stanisław. „Przekład artystyczny jako «samoistny» i «związany» obiekt interpretacji (na przykładzie niektórych polskich tłumaczeń Gottfrieda Benna". W: Z teorii $i$ historii przekładu artystycznego, red. Jacek Baluch. Kraków: Wydawnictwo Uniwersytetu Jagiellońskiego, 1974, 47-74.

Bartmiński, Jerzy. „Wymowa w śpiewie”. W: Opuscula logopaedica: in honorem Leonis Kaczmarek, red. Jerzy Bartmiński. Lublin: Wydawnictwo UMCS, 1993, 226-231.

Bechara, Evanildo. Moderna Gramática Portuguesa. Rio de Janeiro: Nova Fronteira Participações S.A, 2009.

Darasz, Wiktor Jarosław. Mały przewodnik po wierszu polskim. Kraków: Towarzystwo Miłośników Języka Polskiego, 2003.

\footnotetext{
${ }^{30}$ Grażyna Antoniewicz, „Bosa Królowa”, Dziennik Baltycki. Kultura, 18.04.2005, 17. Inne recenzje, podczas kolejnych lat, także były pozytywne: „A na scenie króluje miłość i jeszcze raz miłość. W śpiewie aktorki obok melancholii i zadumy wyczuwa się pasję i niesamowitą energię, a muzyka ma w sobie coś wręcz magicznego. Rozpięta między słodyczą i gwałtownością wzrusza lub skłania do zadumy. Ale zapewniam, że aktorka nie zmarnowała pięknych i mądrych tekstów ubranych w zachwycającą muzykę. Recital cechowała prostota i siła. I tak właśnie brzmi muzyka przeznaczenia, czyli portugalskie fado, które w różnych wykonaniach podbija dziś cały świat”. Taż, „Fatum - piosenki inspirowane portugalskim fado”, Dziennik Battycki. Kultura, 7.07.2010, 19.
} 
Dicionário da língua portuguesa: acordo ortográfico. Porto: Porto Editora, 2011.

García Lorca, Federico. Obras completas I, II, III, red. Arturo del Hoyo. Madrid: Aguilar, 1991.

Klave, Janina. Historia literatury portugalskiej - zarys. Wrocław: Zakład Narodowy im. Ossolińskich, 1985.

Kristeva, Julia. Czarne stońce. Depresja i melancholia. Kraków: Universitas, 2007.

Nowikow, Wiaczesław. Fonetyka hiszpańska. Warszawa: Wydawnictwo Naukowe PWN, 1992.

Pessoa, Fernando. Poesias Inéditas (1919-1930). Lisboa: Ática, 1990.

Pielacińska, Nina. Fenomen fado na przykładzie Polski. Poetyka i performance. Szczecin: Wydawnictwo Naukowe Uniwersytetu Szczecińskiego, 2018.

Pismo Święte Starego i Nowego Testamentu. Częstochowa: Edycja Świętego Pawła, 2009.

Starzycka, Maria Magdalena. „Fado”. W: Stownik rodzajów i gatunków literackich, red. Grzegorz Gazda, Słowinia Tynecka-Makowska. Kraków: Universitas, 2006, 244-246.

Śniedziewski, Piotr. Czarne słońca romantyków. Warszawa: Wydawnictwo Sic!, 2018.

Śniedziewski, Piotr. „Obraz czarnego słońca w wybranych utworach francuskich i polskich romantyków (rekonesans )". Prace Polonistyczne, 70 (2015): 199-202.

Tokarski, Ryszard. Semantyka barw we współczesnej polszczyźnie. Lublin: Wydawnictwo UMCS, 2004.

Vieira, Nery Rui. "A Arte de Dizer". W: Amália: Coração Independente, red. Clara Távora Vilar, Nuno Ferreira de Carvalho. Lisboa: Fundação Amália Rodrigues / Museu Colecção Berrado / Museu da Electricidade-Fundação EDP, 2009, 105-127.

\section{Źródla internetowe}

Fado, pieśń miejska. Dostęp 21.10.2018. http://www.unesco.pl/kultura/dziedzictwo-kulturowe/dziedzictwo-niematerialne/listy-dziedzictwa-niematerialnego/europa-i-ameryka-polnocna/portugalia.

\section{Kilka uwag o tłumaczeniu portugalskiego fado} na przykładzie pieśni Garras dos Sentidos

\section{Streszczenie}

Tematem artykułu są tłumaczenia portugalskich pieśni fado na język polski. Ten gatunek muzyczny uznawany jest za symbol tożsamości narodowej Portugalii i stanowi jeden z najbardziej charakterystycznych wyznaczników jej kultury. Przedmiotem analizy jest pierwsze polskie tłumaczenie wiersza portugalskiej pisarki Agustiny Bessy-Luis Garras dos Sentidos, zaś nadrzędnym celem pracy jest sprawdzenie, czy utwór oryginalny i jego przekład funkcjonują w obydwu kulturach identycznie oraz które elementy tekstu są istotne dla właściwego odbioru. W artykule skoncentrowano się na takich składnikach struktury dzieła, jak wersyfikacja, układ rymów i zjawiska semantyczne. 
Some remarks on the translation of the Portuguese Fado exemplified with the song Garras dos Sentidos

Sum mary

The article concerns translations of Portuguese fado songs into the Polish language. The genre of fado is considered a symbol of the national identity and is one of the most typical elements of the Portuguese culture. The article contains an analysis of the first Polish translation of the poem Garras dos Sentidos written by the Portuguese writer Agustina Bessa-Luís. The analysis has been carried out in order to check whether the original text and its translation function in both cultures in the identical way and which elements of the text are essential to its proper reception. The article concentrates on such components of the structure of the work as versification, the arrangement of rhymes and semantic phenomena.

Cytowanie

Pielacińska, Nina. Kilka uwag o tłumaczeniu portugalskiego fado na przykładzie pieśni Garras dos Sentidos. Studia Językoznawcze. Synchroniczne i diachroniczne aspekty badań polszczyzny 18 (2019): 205-218. DOI: 10.18276/sj.2019.18-14. 